\title{
Urochloa brizantha cv. Marandu presents a better response to in vitro salt stress than other commercial cultivars
}

Paula Beatriz Ramos Guimarães, Mayara de Oliveira Vidotto Figueiredo, Tiago Benedito dos Santos, Alessandra Ferreira Ribas

Universidade do Oeste Paulista - UNOESTE, Presidente Prudente, SP. E-mail: alessandra ribas@hotmail.com

\begin{abstract}
Urochloa brizantha is the main forage grass to raise cattle in Brazil, but salt stress can reduce yield. Physiological and molecular mechanisms of adaptation to salt stress remain poorly understood in this species. The objective of this study was to evaluate the responses of three cultivars of $U$. brizantha to in vitro salt stress. Seeds of three cultivars (Piatã, Marandu, and Xaraés) germinated in filter paper and then transferred to growth on culture media in vitro containing $0,50,100$, and $200 \mathrm{mg} \mathrm{L}^{-1}$ of sodium chloride $(\mathrm{NaCl})$. Biometric parameters and proline content were determined after 28 days. The data were subjected to analysis of variance and the separation of means was performed by the LSD test $(p<0.05)$. Semiquantitative expression of the $\Delta^{1}$-pyrroline-5-carboxylate synthase (P5CS1) gene was performed. In all cultivars, increase of $\mathrm{NaCl}$ concentration in the media affected roots and shoots growth. Xaraes cultivar presented the greater biomass reduction while Marandu cultivar was the least affected. Salt stress increased by approximated 0.6 folds transcription of the P5CS1 gene in all cultivars. However, Marandu cultivar presented a higher proline content and least biomass reduction suggesting a better response to in vitro to salt stress.
\end{abstract}

Key words: abiotic stress; brachiaria grass; salinity.

Urochloa brizantha cv. Marandu apresenta uma melhor resposta ao estresse salino in vitro comparada a outras cultivares comerciais

\begin{abstract}
Resumo
Urochloa brizantha é a principal gramínea forrageira para a pecuária no Brasil, mas o estresse salino pode reduzir a produtividade. Os mecanismos fisiológicos e moleculares de adaptação ao estresse salino permanecem pouco conhecidos nesta espécie. O objetivo desse estudo foi avaliar as respostas de três cultivares de $U$. brizantha ao estresse salino in vitro. Sementes de três cultivares (Piatã, Marandu e Xaraés) germinaram em papel filtro e foram transferidas para cultivo em meio in vitro contendo 0, 50, 100 e 200 mg L-1 de cloreto de sódio $(\mathrm{NaCl})$. Os parâmetros biométricos e o conteúdo de prolina foram determinados após 28 dias. Os dados foram submetidos à análise de variância e separação de médias realizada pelo teste $\operatorname{LSD}(p<0,05)$. Foi realizada a expressão semiquantitativa do gene da $\Delta^{1}$-pirrolina-5-carboxilato sintase (P5CS1). Em todas as cultivares, o aumento da concentração de $\mathrm{NaCl}$ no meio afetou o crescimento das raízes e da parte aérea. A cultivar Xaraes apresentou a maior redução na biomassa enquanto Marandu foi a menos afetada. $O$ estresse salino foi aumentado pela transcrição de aproximadamente 0,7 vezes do gene P5CS1 em todas as cultivares. No entanto, a cultivar Marandu apresentou maior teor de prolina e menor redução de biomassa, sugerindo melhor resposta ao estresse salino in vitro.
\end{abstract}

Palavras-chave: estresse abiótico; capim braquiária; salinidade.

\section{Introduction}

The Paniceae tribe is originally from Africa, counts on 100 species, among them the important forage grasses from Urochloa P. genus (sin. Brachiaria) Beauv. spp. (SORENG et al., 2017). The Urochloa sp composes an agamic 
complex with different levels of ploidy (VALLE et al., 2009). Urochloa brizantha produce apomictic seeds that are clones and few cultivars are commercially available (VALLE et al., 2010). In Brazil, it is estimated that about $100 \mathrm{M}$ ha are cropped with tropical forage grasses (PEREIRA et al., 2018) and from the total, $85 \%$ consist of Urochloa species (JANK et al., 2014). One of the main goals for breeding of tropical forages in Brazil is to develop or to select cultivars tolerant to the climate changes (PEREIRA et al., 2018).

Salt stress is one of the most threatening abiotic stresses that limits plant growth and development. Several efforts have been made to understand the responses to salt stress and exploring genotype toleranceassociated will be particularly essential in the future (ZHAO et al., 2020). During salt stress, the reduction in water availability causes an increase in the respiration rate and poor distribution of minerals causing instability of the membranes and failure to maintain the cell turgor pressure (BABU et al., 2012). Tolerance to salinity consists of numerous processes at physiological, cellular, biochemical, and molecular levels, allowing plants survival (ACOSTA-MOTOS et al., 2017). Such changes include increases in the root/shoot ratio and chlorophyll content, as well as changes in leaf anatomy, preventing toxicity by the accumulation of ions in the leaves, preventing water loss, and protect the photosynthesis process (ARIF et al., 2020). At the molecular level, the expression of several genes related in response to salt stress. One of these genes is $\Delta^{1}$ pyrroline-5-carboxylate synthase (P5CS1) whose transcription in plants is induced by osmotic stresses including dehydration, salinity, low and high temperatures (SIDDIQUE et al., 2018; TROVATO et al., 2019). The proline biosynthesis is mainly via the glutamate pathway, which includes two enzymes and non-enzymatic reactions that occur in the cytoplasm or chloroplast and are catalyzed by $\Delta^{1}$-pyrroline-5-carboxylate synthase $(P 5 C S)$ and $\Delta^{1}$-pyrroline-5-carboxylate reductase $(P 5 C R)$, respectively (AMINI et al., 2015). The increase in the transcription of the P5CS1 gene can result in a greater accumulation of proline and consequently, plants are more resistant to salt stress (BENITEZ et al., 2016). Therefore, the genes involved in the accumulation of proline are the key to progress in understanding this process and the impact on stress tolerance.

The imposition of salt stress in vitro is an effective strategy for the selection and characterization of plant responses to salinity in several species including Oryza sativa (TEH et al., 2015), Camelina sativa (KHALID et al., 2015), Carthamus tinctorius (HAMEDI et al., 2016), Lathyrus sativus (PIWOWARCZYK et al., 2016), Amsonia orientalis (ACEMI et al., 2017). Therefore, the in vitro cultivation of Urochloa sp cultivars under salt stress can be an alternative for the initial evaluation concerning salinity tolerance. The objective of this study was to evaluate the biometric parameters and the semi quantitative expression of P5CS gene and the proline content of three $U$. brizantha cultivars subjected to different levels of salt stress under in vitro culture.

\section{Material and Methods}

Plant material

Before starting the experiment with salinity, the percentage of germination of the seeds of the commercial cultivars of $U$. brizantha, (Marandu, Xaraes, and Piatã) was tested. This step was carried out to ensure that all seeds tested in the saline media were able to germinate normally. The seeds were scarified by immersion in concentrated sulfuric acid $\left(\mathrm{H}_{2} \mathrm{SO}_{4}\right)$ for 15 minutes, shaking with a glass stick, washed in running water to remove excess acid, and then the seeds were dried on paper towels at room temperature. After drying, the scarified seeds were manually peeled, and immersed in $70 \%$ ethanol for $15 \mathrm{~s}$. After the seeds were transferred for a $5 \%$ sodium hypochlorite $(\mathrm{NaOCl})$ solution containing three drops of Tween 80, for 15 minutes, and then rinsed 5 times in sterile distilled water. All the disinfection process was conducted in a superficial laminar flow chamber.

\section{Growth conditions and stress treatment}

One hundred seeds of each cultivar were pre-germinated in Petri dishes containing filter paper and water in a proportion of 2 times the weight of the paper. The plates were kept in the dark for seven days. After that period, the germinated seeds were transferred to the basic culture medium composed of macro, microelements, and vitamins from the MS culture medium (MURASHIGE; SKOOG, 1962) with $30 \mathrm{~g} \mathrm{~L}^{-}$ ${ }^{1}$ of sucrose agar. To impose salt stress, sodium chloride $(\mathrm{NaCl})$ was added in concentrations of 0 , 50,100 and $200 \mathrm{mg} \mathrm{L}^{-1}$ to the basic MS medium. The $\mathrm{pH}$ was adjusted to 5.8 and $8 \mathrm{~g} \mathrm{~L}^{-1}$ of agar was added to solidify the media. The culture media were distributed in test tubes, $10 \mathrm{ml}$ in each. 
Seeds pre-germinated on filter paper for 7 days were distributed in the test tubes containing the different concentrations of $\mathrm{NaCl}$. The experiment was carried out with six replicates for each cultivar and treatment. All plant materials were grown in a culture room at $25 \pm 1{ }^{\circ} \mathrm{C}$ under a photoperiod of $16 / 8 \mathrm{~h}$ of light and luminous intensity of $30 \mu \mathrm{mol} \mathrm{m} \mathrm{m}^{-2}$. After 28 days in the culture media with salt treatments, the plants were removed from the test tubes. The shoots were separated from the roots, and were weighed on an electronic scale to determine the fresh mass. The length of the aerial part and roots were measured with the aid of a graduated ruler.

\section{Semi Quantitative PCR}

Total RNA was extracted from $50 \mathrm{mg}$ of leaf tissue from treatments using the Pure Link Plant $^{\mathrm{TM}}$ RNA Reagent (Invitrogen, Carlsbad, CA, USA) according to the manufacturer's protocol. The samples were treated with the Turbo DNAse enzyme (Ambion) to eliminate contamination with genomic DNA, following the manufacturer's protocol. The concentration of the total extracted RNA was measured by spectrophotometry at 260 $\mathrm{nm}$, its quality estimated at the 260/280 nm ratio, and the integrity by $1.2 \%(\mathrm{w} / \mathrm{v})$ agarose gel electrophoresis.

The synthesis of cDNA was performed following the protocol of the Ready Script Kit cDNA Synthesis $\mathrm{Mix}^{\mathrm{TM}}$ (Sigma Aldrich) from the total RNA extracted from the leaves. This cDNA was subjected to a PCR reaction with the specific primers of the normalizing gene elF4A, to verify whether they amplified the expected fragment. This gene was chosen among a panel of seven reference genes previously tested in our laboratory in $U$. brizantha submitted to salt stress.

For the PCR reaction, the protocol of the SuperMix PCR Kit ${ }^{\mathrm{TM}}$ (Invitrogen, Carlsbad, CA, USA) was followed and the samples were subjected to electrophoresis in $1.5 \%(\mathrm{w} / \mathrm{v})$ agarose gel. The design of the primer to amplify a fragment of the P5CS1 gene was based on orthology in species of the Panicoideae family (same as that of $U$. brizantha) since this species does not have its genome sequenced and available in the databases. Firstly, we use the keyword P5CS1 in the database: The Arabidopsis Information Resource (https://www.arabidopsis.org/) and found the sequence corresponding to P5CS1 (AT2G39800).
This sequence was used as a query to search for sequences from Panicoideae species, in the Phytozome database (https://phytozome.jgi.doe.gov/pz/portal.html) using the blast tool. We found six sequences Panicum halli (C02762.1), Panicum virgatum (J06546.1), Setaria italica (3G220500.1), Setaria viridis (3G225500.1), Sorghum bicolor (009G160100) and Zea mays (GRMZM2G375504). These sequences were aligned and a pair of primer to amplify a fragment of (91 bp) was designed: 5'-CCAGTGGGTGTTGAAGGTCT-3' and 5'GGGTGTAGGCAACATCCTTG-3' at conserved region. The gene elF4A (eukaryotic initiation factor) was used to normalize the data (TAKAMORI et al., 2017). The primers were used to evaluate the relative expression of the P5CS1 gene in the three $U$. brizantha cultivars grown in vitro in different concentrations of $\mathrm{NaCl}$.

RT-PCR reactions (reverse transcriptase polymerase chain reaction) were performed in a Multigene Biosystems ${ }^{\mathrm{TM}}$ thermal cycler. The 35 times cycle was chosen for both P5CS1 genes and the normalizer elF4A (eukaryotic initiation factor) with the following conditions: $95^{\circ} \mathrm{C}$ for $2 \mathrm{~min}$ and 35 times $95^{\circ} \mathrm{C}$ for $30 \mathrm{~s}, 60^{\circ} \mathrm{C}$ for $30,1 \mathrm{~min}$ at 72 ${ }^{\circ} \mathrm{C}$ and $2 \mathrm{~min}$ at $72{ }^{\circ} \mathrm{C}$ of final extension. The amplicons of both genes were submitted to electrophoresis in 1.5\% agarose gel. The gels were ethidium bromide-stained photographed under UV light. The quantification of amplicons was calculated by densitometry using the ImageJ software. The relative expression was calculated by quantifying the P5CS1 gene in each treatment divided by the normalizing (eIF4A gene) quantification. The data were calibrated by the zero treatment (without the addition of $\mathrm{NaCl}$ ) in each cultivar.

Proline content

The determination of proline content was carried out as previously described (BATES et al., 1973) with modifications. In brief, $25 \mathrm{mg}$ of plant tissue (shoots) grown in vitro were macerated in liquid nitrogen, $2.5 \mathrm{ml}$ of sulfosalicylic acid (3\%) added, vortexed followed by $15 \mathrm{~min}$. The samples were centrifuged at 5000 $\mathrm{g}$ for $3 \mathrm{~min} .1 \mathrm{ml}$ of the supernatant was removed and $1 \mathrm{ml}$ of acid ninhydrin and $1 \mathrm{ml}$ of glacial acetic acid were added. The samples remained in a water bath at $100{ }^{\circ} \mathrm{C}$ for $1 \mathrm{~h}$ and then cooled on ice. Two $\mathrm{ml}$ of toluene was added to each sample and vortexed for $20 \mathrm{~s}$. The samples remained for $5 \mathrm{~min}$ at room temperature to separate the 
phases. $1 \mathrm{ml}$ of the aqueous phase (supernatant) was removed to quantify proline content by spectrophotometry at $520 \mathrm{~nm}$. The analyzes were performed in triplicate and the concentration of proline was determined using a standard curve $(0$ - $100 \mu \mathrm{g} \mathrm{mL}^{-1}$ ) and expressed in micromol of proline per gram of fresh mass $\left(\mu \mathrm{mol} \mathrm{g} \mathrm{MF}^{-1}\right)$.

\section{Statistics Analysis}

All results were subjected to analysis of variance (ANOVA). Significant differences between means were determined using the Least Significant Difference (LSD test) at a level of $p$ $<0.05$.

\section{Results and Discussion}

Plant growth under salt stress activates several responses to survive including physiological, biochemical, and molecular changes that affect plant growth and development (SZABADOS; SAVOURE, 2009). In this work, we evaluated three cultivars of $U$. brizantha (Marandu, Piatã and Xaraés) to in vitro salt stress. After seven days seeds germinated in filter paper were transferred to test tubes with or without $\mathrm{NaCl}$ and remained for 28 days old (Figure 1A). After this time, the plantlets were removed from the test tubes (Figure $1 B$ ). The shoots and roots growth were inversely affected by the increase in the concentration of $\mathrm{NaCl}$ in the media culture. This result was observed in all cultivars tested. Seedlings showed a vitrified aspect at $200 \mathrm{mg} \mathrm{L}^{-1} \mathrm{NaCl}$ in all the three cultivars (Figure 1B).

Figure 1. Seedling growth characteristics of the three cultivars of $U$. brizantha in MS medium with different $\mathrm{NaCl}$ concentrations after 28 days. Xaraes (A, D); Marandu (B, E); Piatã (C, F).
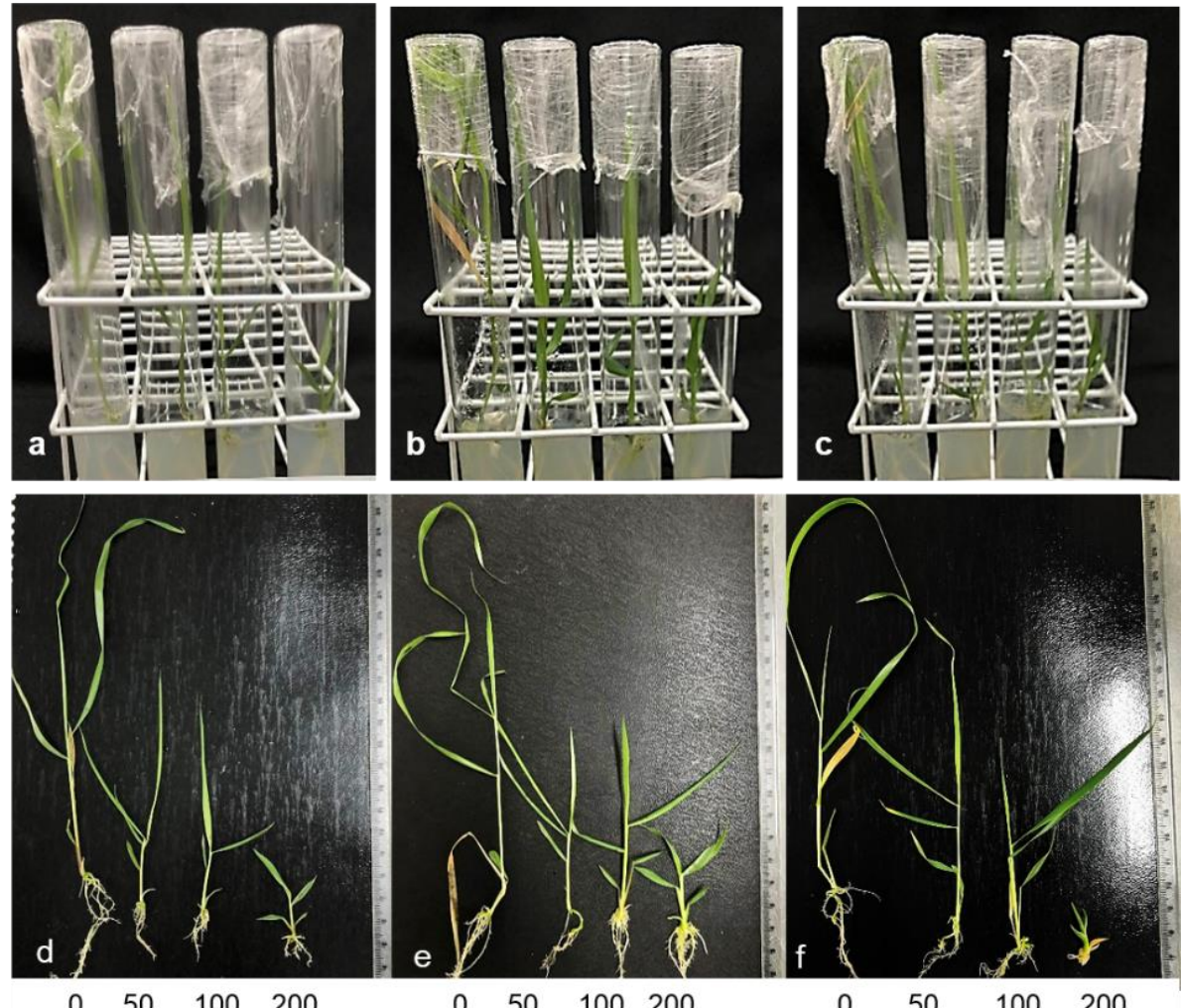

$0 \quad 50 \quad 100 \quad 200$

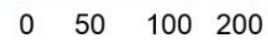

$\begin{array}{llll}0 & 50 & 100 & 200\end{array}$

$m g L^{-1}$ de $\mathrm{NaCl}$

The Xaraés cultivar showed significant reductions in fresh weight of shoots from $50 \mathrm{mg}$ $\mathrm{L}^{-1}$ while Piatã and Marandu only at $200 \mathrm{mg} \mathrm{L}^{-1}$ of $\mathrm{NaCl}$ (Figure 2A). The root fresh weight was only significant for the Marandu cultivar (Figure 2B). The shoots length were significantly reduced by the addition of $50 \mathrm{mg} \mathrm{L}^{-1} \mathrm{NaCl}$ to the media in all cultivars. The reduction in growth was 73,88 , and $72 \%$ for the cultivars Xaraés, Piatã, and Marandu, respectively (Figure $2 \mathrm{C}$ ). The Piatã cultivar showed significant reductions in root length from $50 \mathrm{mg} \mathrm{L}^{-1}$, while for Xaraés and Marandu from 
$100 \mathrm{mg} \mathrm{L}^{-1}$ (Figure 2D). The most drastic reduction was observed at $200 \mathrm{mg} \mathrm{L}^{-1} \mathrm{NaCl}$ in all cultivars in the order of $80 \%$ for cultivars Xaraés and Piatã and $51 \%$ for Marandu (Figure 2D).

Figure 2. Biometric measurements of shoots and roots at three cultivars of $U$. brizantha after 28 days in vitro with different concentrations of $\mathrm{NaCl}$. (AB) Fresh weight $(\mathrm{mg}), \mathrm{CD}$ Length $(\mathrm{cm})$. Capital letters compare the three cultivars at each $\mathrm{NaCl}$ concentration and lower-case letters compare each cultivar on the four $\mathrm{NaCl}$ concentrations. Different letters indicate the statistical difference between the means of treatments by the LSD test $(p<0.05)$. The error bar indicates the mean $(n=6)$ standard error. Bars=SE.

a

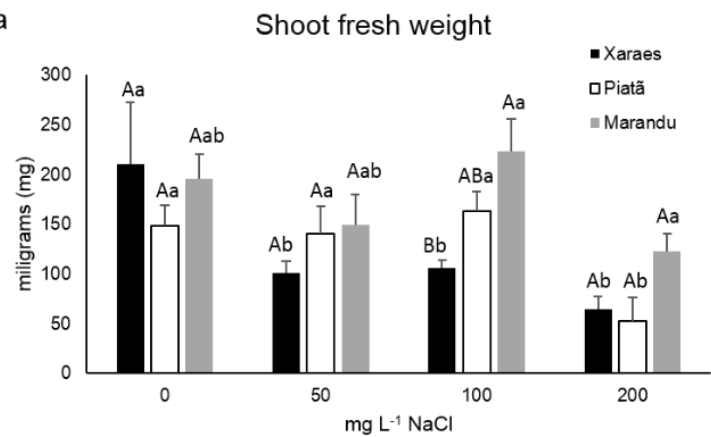

C

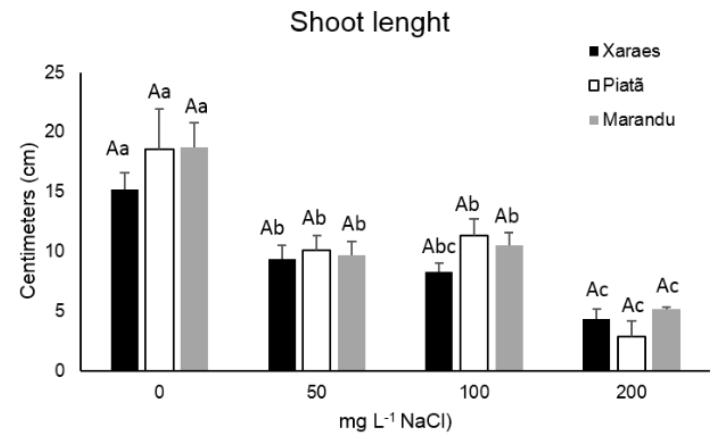

Plants under salt stress immediately start a rapid osmotic phase resulting in an increase of sodium concentration $\left(\mathrm{Na}^{+}\right)$in plant cells that inhibit potassium $\left(\mathrm{K}^{+}\right)$uptake (САВOT et al., 2014). Potassium is an indispensable element, consequently, plants reduce growth and development when it is deficient (GUPTA; HUANG, 2014). Tolerance to salinity varies with plant species and even within the same species. Although, Marandu cultivar also decreased growing when the $\mathrm{NaCl}$ increased; it was the least affected by salinity because their leaves became wider at concentrations of 100 and $200 \mathrm{mg} \mathrm{L}^{-1}$ $\mathrm{NaCl}$, resulting in a less reduction in fresh mass weight (Figure 1B and E). In Lathyrus sativus (chícharo), exposure to salt in vitro significantly reduced the length of the roots and the shoot, but did not influence the dry mass of the shoot and even increased in the roots (PIWOWARCZYK et al., 2016). It is believed that tolerance to salinity may be associated with increased or not reduced mass in stressed plants compared to the control (TALUKDAR, 2011). Plants can tolerate

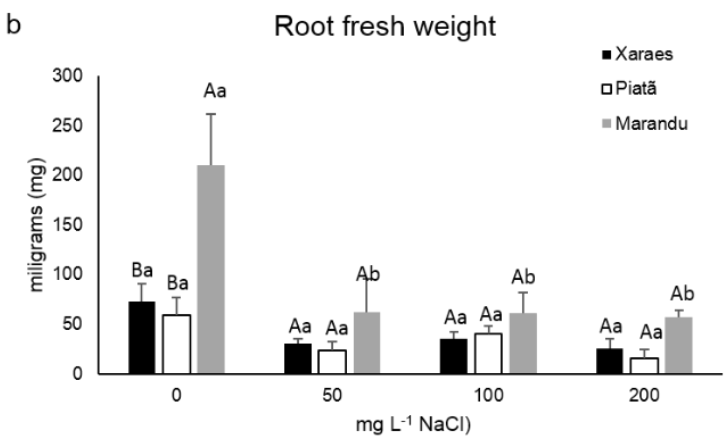

d

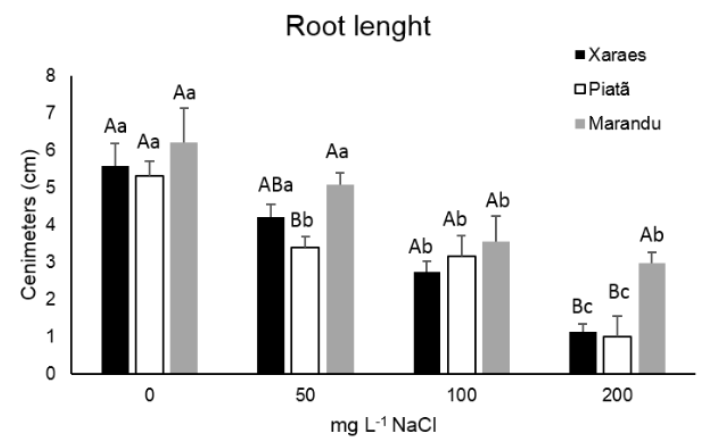

low levels of salt stress by extrusion of $\mathrm{Na}^{+}$ions out of the cell and or trapping it at the vacuoles (MUNNS; TESTER, 2008). Comparing two cultivars of basil (Ocimum basilicum) under salt stress it was found that the cultivar more tolerant improved water balance preserving photosynthesis, accumulated lower abscise acid and higher $\mathrm{Na}^{+}$in leaves that can function as an osmoticum resulting in less reduction on the biomass accumulation than the sensitive cultivar (MANCARELLA et al., 2016). Salt stress reduced the growth in the three $U$. brizantha cultivars however we observed that Marandu cultivar leaves were wider resulting in the least reduction of shoots biomass. We hypothesize that it could be a result of compartmentalization of $\mathrm{Na}^{+}$íns on the vacuoles increasing leaves area.

Several abiotic stresses including salinity lead to biochemical changes that increase the biosynthesis of compatible solutes such as proline, which play an important role in mitigating the effects of stress, helping to maintain the integrity of membranes, and 
eliminating oxygen-reactive species (ALI et al., 2017). To estimate the semi-quantitative expression of the P5CS1 gene and proline content we use the samples from the three cultivars (Marandu, Piatã and Xaraés) growing in vitro at 0 and $100 \mathrm{mg} \mathrm{L}^{-1} \mathrm{NaCl}$. This concentration was chosen because in most cases, there was no significant difference between 50 and $100 \mathrm{mg} \cdot \mathrm{L}^{-1}$ for the biometric parameters and the decrease in growth at $200 \mathrm{mg} \mathrm{L}^{-1} \mathrm{NaCl}$ was so drastic that there was not enough material for RNA extraction. Since there is no genome available for $U$. brizanha, we designed a primer to amplify a fragment of the P5CS1 gene on a conserved sequence from six species from the Panicoideae family. The sequence alignment showed that the P5CS1 gene is highly conserved among them. A conventional PCR was conducted using the designed pair of primers and polled samples from all cDNAs. Agarose gel electrophoresis revealed the presence of a single band of the expected size 81 bp for P5CS1 (Figure 3A). In this work, the addition of $100 \mathrm{mg} \cdot \mathrm{L}^{-1} \mathrm{NaCl}$ to the culture media led to an increase in the transcription of the P5CS1 gene ( 0.6 fold) in all cultivars (Figure $3 B$ ). The P5CS gene encodes is a bifunctional enzyme that catalyzes proline biosynthesis, an osmoprotectant that protects the cell against abiotic stresses (RAl; PENNA, 2013).

Figure 3. Semi-quantitative PCR on $1.5 \%$ agarose gel stained with ethidium bromide (A). Relative expression of the P5CS1 gene normalized with the elF4A gene and calibrated with the zero treatment in each cultivar (B). Capital letters compare the three cultivars at the same $\mathrm{NaCl}$ concentration and lower case letters compare each cultivar at 0 and $100 \mathrm{mg} . \mathrm{L}-1 \mathrm{NaCl}$. Different letters indicate the statistical difference between the means of treatments by the LSD test $(p<0.05)$. Error bar indicates the standard error of the mean $(n=$ 3). Bars=SE.

A

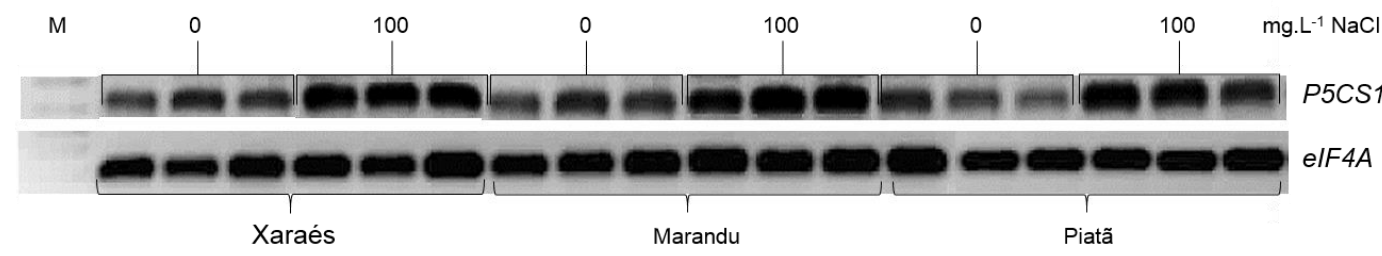

B

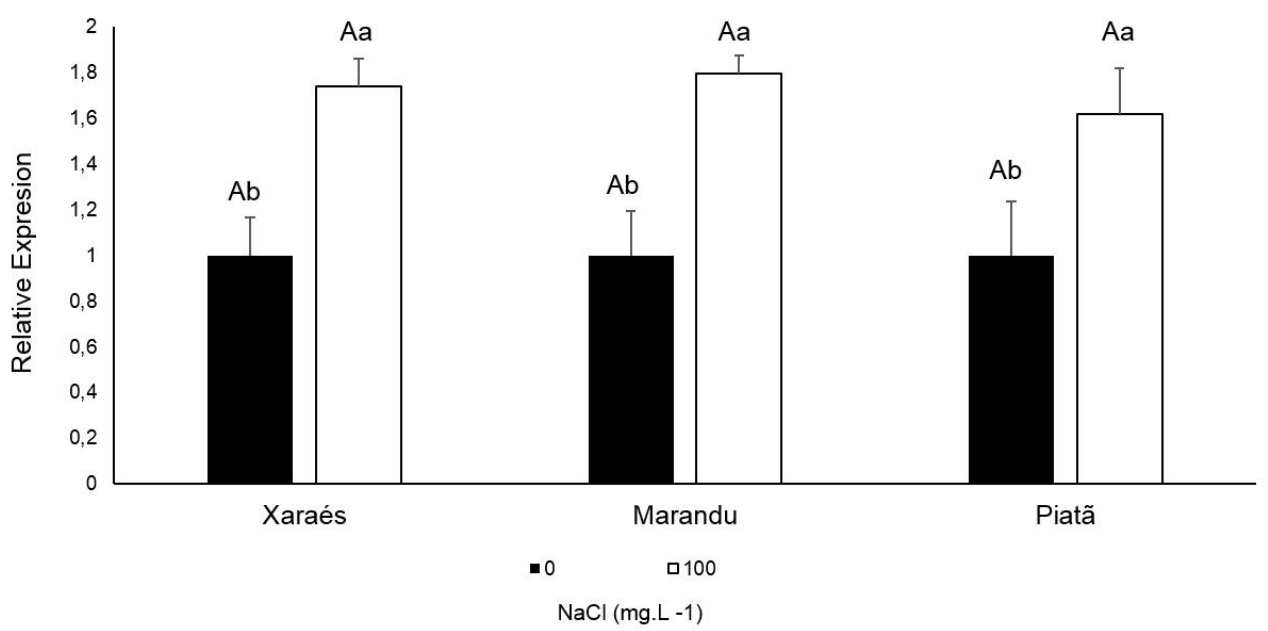

In most plant species, increased transcription of the P5CS gene and concentration of proline are positively related to stresses (ZHANG; BECKER, 2015). This increase in the transcription of the P5CS1 gene depends on the species, the growth stage, and the salt concentration used (ANNUNZIATA et al., 2016). We observed that all $U$. brizantha cultivar increased transcription of $P 5 C S 1$ under salt stress at the same level. Estimation of proline content revealed that it significantly increased in the three cultivars of Urochloa sp grown at $100 \mathrm{mg} \mathrm{L}^{-1}$ $\mathrm{NaCl}$ on culture media. The increase was 4.2, 3.8, and 8.2 times for cultivars Xaraés, Piatã, and Marandu, respectively, when compared to the treatment without salt addition (Figure 4). Plants 
under abiotic stress increase the concentration of

endogenous proline. Cultivar Marandu accumulated significantly more proline than the other two cultivars (Figure 4).

Figure 4. Determination of proline content in 3 cultivars of $U$. brizantha cultivated in vitro without and with the presence of $100 \mathrm{mg} . \mathrm{L}-1 \mathrm{NaCl}$. Capital letters compare the three cultivars at the same $\mathrm{NaCl}$ concentration and lower case letters compare each cultivar at 0 and $100 \mathrm{mg} . \mathrm{L}-1 \mathrm{NaCl}$. Different letters indicate the statistical difference between the means of treatments by the LSD test $(p<0.05)$. Error bar indicates the standard error of the mean $(n=3)$. Bars=SE.

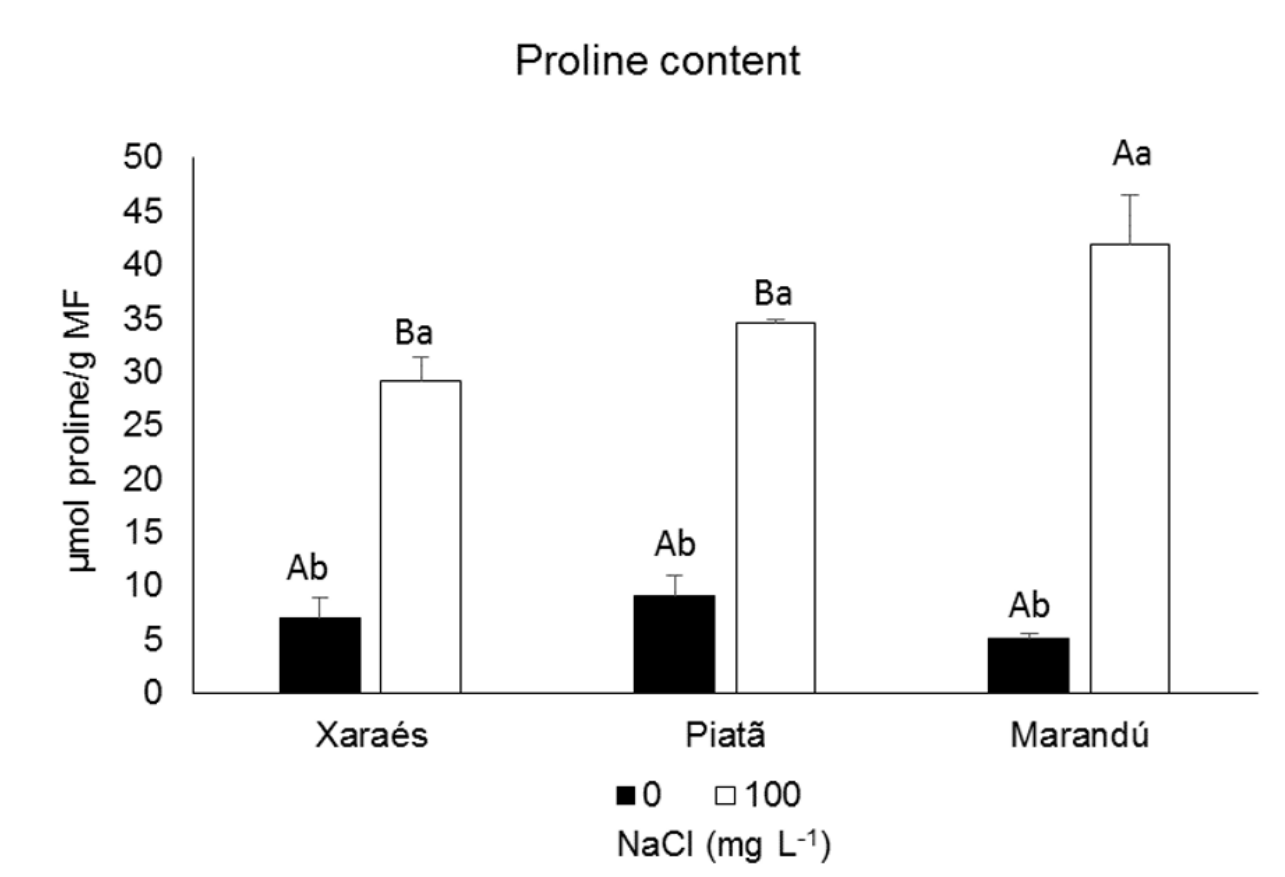

In general, gene transcription increases a few hours after the salt stress imposition (PER, 2017). Although the transcriptional level of the P5CS1 genes was similar at the concentration of $100 \mathrm{mg} \mathrm{L}^{-1} \mathrm{NaCl}$ in the three cultivars, proline content was higher in cv. Marandu. This may have occurred because the relative expression of the P5CS1 gene and the determination of proline content were performed after 28 days of in vitro growth in the presence or absence of $\mathrm{NaCl}$. In Arabidopsis, for example, seedlings grown at 170 $\mathrm{mM} \mathrm{NaCl}$, the accumulation of P5CS transcripts started $4 \mathrm{~h}$ after treatment, reached its maximum level after 8 hours, and then decreased for the next 24 hours (AMINI et al., 2015). In this way, it is possible that the transcriptional level of P5CS1 in $U$. brizantha was already stabilized at that time and the possible differences between cultivars could not be observed.

\section{Conclusion}

In this work, the addition of any concentration of $\mathrm{NaCl}$ to the in vitro culture media reduced the growth of shoots and roots and increased the transcription of P5CS gene in all three cultivars of brachiaria assayed. However, Marandu cultivar showed a lower reduction in the fresh weight of shoots and roots compared to Piatã and Xaraés. This could be the result of the greater accumulation of proline in Marandu cultivar, since this amino acid act as an osmoprotectant against salt stress. The results presented here suggest that Marandu could present a better response of adaptation to in vitro salt stress.

\section{Acknowledgment}

Paula Beatriz Ramos Guimarães is grateful for a grant from the National Council for Scientific and Technological Development (PIBICCNPq) - Brazil. We are grateful to Cristiane Aparecida de Souza for technical assistance in the tissue culture laboratory- UNOESTE. 


\section{References}

ACEMI, A.; DUMAN, Y.; KARAKUS, Y. Y. ; YASEMIN, O. K.; ÖZEN, F. Analysis of plant growth and biochemical parameters in Amsonia orientalis after in vitro salt stress. Horticulture Environmental and Biotechnology, v.58, p.231239, 2017. https://doi.org/10.1007/s13580-0170215-0

ACOSTA-MOTOS, J. R.; ORTUÑO, M. F.; BERNAL, V. A.; DIAZ, V. P.; SANCHEZ, B. M. J. E.; HERNANDEZ, J. Á. Plant responses to salt stress: adaptive mechanisms. Agronomy, v.7, p.18, 2017. https://doi.org/10.3390/agronomy7010018

ALI, F.; BANO, A.; FAZAL, A. Recent methods of drought stress tolerance in plants. Plant Growth Regulation, v.82, p.363-375, 2017. https://doi.org/10.1007/s10725-017-0267-2

AMINI, K.; PLANCHAIS, S.; CABASSA, C. Different proline responses of two algerian durum wheat cultivars to in vitro salt stress. Acta Physiologiae Plantarum, v.42, p.21, 2015. https://doi.org/ $\underline{10.1007 / s 11738-019-3004-9}$

ARIF, Y.; SINGH, P.; SIDDIQUI, H.; BAJGUZ, A.; HAYAT, S. Salinity induced physiological and biochemical changes in plants: An omic approach towards salt stress tolerance. Plant Physiology Biochemistry, v.156, p.64-77, 2020. https://doi.org/10.1016/i.plaphy.2020.08.042

ANNUNZIATA, M. G.; CIARMIELLO, L. F.; WOODROW, P.; MAXIMOVA, E.; FUGGI, A. E.; CARILLO, P. Durum wheat roots adapt to salinity remodeling the cellular content of nitrogen metabolites and sucrose. Frontiers in Plant Science, v.7, p.2035, 2016. https://doi.org/10.3389/fpls.2016.02035

BABU, M. A.; SINGH, D. E.; GOTHANDAM, K. M. The effect of salinity on growth, hormones and mineral elements in leaf and fruit of tomato cultivar Pkm1. Journal of Animal and Plant Science, v.22, p.159-164, 2012.

BATES, L.; WALDREN, R. P. E.; TEARE, I. D. Rapid determination of free proline for water-stress studies. Plant and Soil, v.39, p.205-207, 1973. https://doi.org/10.1007/BF00018060

BENITEZ, L. C.; VIGHI, L. ; AULER, P. A. ; AMARAL, M. N. ; MORAES, G. P.; RODRIGUES, G. S.;
MAIA, L. C.; MAGALHÃES JÚNIOR, A. M.; BRAGA, E. J. B. Correlation of proline content and gene expression involved in the metabolism of this amino acid under abiotic stress. Acta Physiologiae Plantarum, v.38, p.267, 2016. https://doi.org/10.1007/s11738-016-2291-7

CABOT, C.; SIBOLE, J. V.; BARCELÓ, J.; POSCHENRIEDER, C. Lessons from crop plants struggling with salinity. Plant Science, v.226, p.213 , 2014. https://doi.org/10.1016/j.plantsci.2014.04.013

GUPTA, B.; HUANG, B. R. Mechanism of salinity tolerance in plants: Physiological, biochemical, and molecular characterization. International Journal of Genomics, n.701596, 2014 https://doi.org/10.1155/2014/701596

HAMEDI, M.; GOLKAR, P. E.; ARZANI, A. In vitro salt tolerance of safflower (Carthamus tinctorius L.) genotypes using different explants. Plant Tissue Culture and Biotechnology, v.26, p.231242, 2016.

https://doi.org/10.3329/ptcb.v26i2.30573

JANK, L.; BARRIOS, S. C.; VALLE, C. B.; SIMEÃO, R. M.; ALVES, G. F. The value of improved pastures to Brazilian beef production. Crop and Pasture Science, v.65, p.132-1137, 2014 https://doi.org/10.1071/CP13319

KHALID, H.; KUMARI, M.; GROVER, A.; NASIM, M. Salinity stress tolerance of camelina investigated in vitro. Scientia Agriculturae Bohemica, v.4, p.137-144, 2015. https://doi.org/10.1515/sab2015-0028

MANCARELLA, S. ; ORSINIA, F. ; VAN OOSTEN, M. J.; SANOUBARA, R. ; STANGHELLINI, C.; KONDO, S.; GIANQUINTO, G.; MAGGIO, A. Leaf sodium accumulation facilitates salt stress adaptation and preserves photosystem functionality in salt stressed Ocimum basilicum. Environmental and Experimental Botany, v.130, p.162-173, 2016. https://doi.org/10.1016/i.envexpbot.2016.06.004

MUNNS, R.; TESTER, M. Mechanisms of salinity tolerance. Annual Review Plant Biology, v.59, p.651-681, 2008. https://doi.org/10.1146/annurev.arplant.59.0326 07.092911 
MURASHIGE, T.; SKOOG, F. A revised medium for rapid growth and bio assays with tobacco tissue cultures. Physiologiae Plantatarum, v.15, p.473497, 1962. https://doi.org/10.1111/i.13993054.1962.tb08052.x

PER, T. S. Approaches in modulating proline metabolism in plants for salt and drought stress tolerance: Phytohormones, mineral nutrients and transgenics. Plant Physiology Biochemistry, v.115, p.126-140, 2017. https://doi.org/10.1016/j.plaphy.2017.03.018

PEREIRA, J. F.; AZEVEDO, A. L. S.; PESSOA-FILHO, M.; ROMANEL, E. A. C.; PEREIRA, A. V. et al., Research priorities for next-generation breeding of tropical forages in Brazil. Crop Breeding and Applied Biotechnology, v. 18, p. 314-319, 2018. https://doi.org/10.1590/1984$\underline{70332018 v 18 n 3 n 46 .}$.

PIWOWARCZYK, B.; TOKARZ, K. E.; KAMINSKA, I. Responses of grass pea seedlings to salinity stress in in vitro culture conditions. Plant Cell Tissue and Organ Culture, v. 124, p. 227-240, 2016. https://doi.org/10.1007/s11240-015-0887-z

RAI, A. N.; PENNA, S. Molecular evolution of plant P5CS gene involved in proline biosynthesis. Molecular Biology Reports, v. 40, p.6429-6435, 2013. https://doi.org/10.1007/s11033-013-27572

SIDDIQUE, A.; KANDPAL, G.; KUMAR, P. Proline accumulation and its defensive role under diverse stress conditions in plants: An Overview. Journal of Pure and Applied Algebra, v.12, p. 1655-1659, 2018. https://dx.doi.org/10.22207/JPAM.12.3.73

SZABADOS, L.; SAVOURE, A. Proline: a multifunctional aminoacid. Trends in Plant Science, v.15, p.89-97, 2009. https://dx.doi.org/10.1016/i.tplants.2009.11.009

SORENG, R. J.; PETERSON, P. M.; ROMASCHENCO, K.; DAVIDSE, G.; TEISHER, J. K. CLARK, L. G.; BARBERÁ, P.; GILLESPIE, L. J.; ZULOAGA, F. O. $A$ worldwide phylogenetic classification of the Poaceae (Gramineae) II: An update and a comparison of two 2015 classifications. Journal of Systematic Evolution, v.55, p.259-290, 2017. https://doi.org/10.1111/ise.12262
TALUKDAR, D. Isolation and characterization of $\mathrm{NaCl}$-tolerant mutations in two important legumes, Clitoria ternatea $\mathrm{L}$. and Lathyrus sativus L.: induced mutagenesis and selection by salt stress. Journal of Medicinal Plants Research, v.5, p.3619-3628, 2011.

TAKAMORI, L. M.; PEREIRA, A. V. C.; SOUZA, G. M.; VIEIRA, L. G. E.; RIBAS, A. F. Identification of endogenous reference genes for RT-qPCR expression analysis in Urochloa brizantha under abiotic stresses. Scientific Reports, v.7, p.1-11, 2017. https://doi.org/10.1038/s41598-01709156-7

THE, C. Y.; MAHMOOD, M.; SHAHARUDDIN, N. A. H. O. $\mathrm{CH}$. In vitro rice shoot apices as simple model to study the effect of $\mathrm{NaCl}$ and the potential of exogenous proline and glutathione in mitigating salinity stress. Plant Growth Regulator, v.75, p. 771-781, 2015. https://doi.org/10.1007/s10725-014-9980-2

TROVATO, M.; FORLANI, G.; SIGNORELLI, S.; FUNCK, D. Proline metabolism and its functions in development and stress tolerance. In: HOSSAIN, M.; KUMAR, V.; BURRITT, D.; FUJITA, M.; MÄKELÄ, P. (eds). Osmoprotectant-mediated abiotic stress tolerance in plants. Cham: Springer, $2019.21-72 p$. https://doi.org/10.1007/978-3-030-27423-8 2

VALLE, C. B.; JANK, L. E.; RESENDE, R. M. S. O melhoramento de forrageiras tropicais no Brasil. Revista Ceres, v.56, p.460-472, 2009.

VALLE, C. B.; MACEDI, M. C. C.; EUCLIDES, V. P. B.; JANK, L. E.; RESENDE, R. M. S. Gênero Brachiaria. In: Fonseca DM e Martuscello JÁ. Plantas forrageiras. 1.ed. Viçosa: Editora UFV, 2010. 327$353 p$.

ZHANG, L.; BECKER, D. F. Connecting proline metabolism and signaling pathways in plant senescence. Frontiers Plant Science, v.6, p.1-8, 2015. https://doi.org/10.3389/fpls.2015.0055

ZHAO, C. H.; ZHANG, H.; JIAN, C. S.; ZHU, K.; SHABA, S. Mechanisms of Plant Responses and Adaptation to Soil Salinity. The Innovation, v.1, p.100017, 2020. https://doi.org/10.3389/fpls.2015.00552 